\title{
Swift and Humour: an Intellectual as a Political Figure
}

\author{
Swift ve Mizah: Siyasi Bir Karakter Olarak Entellektüel
}

\begin{abstract}
Mehmet Ali ÇELİKEL*
Abstract: An intellectual as a public figure contributes to the world of ideas and plays a key role in the politics of his or her own society. It has always been hard to define the intellectual as a productive and beneficial identity for society. Jonathan Swift questioned the politics of his time and of the place of the intellectual in it, questioned who the intellectual was and why he or she deserved to be called one in Gulliver's Travels. Gulliver's Travels suggests alternative worlds in which academics are depicted as spoof figures, profane spokespersons of scientific knowledge. Lemuel Gulliver is a political figure who has to analyse and interpret the political atmosphere of the fantastic lands to which he travels. The aim of this study was to analyse how the difficulties of intellectuals are translated in Gulliver's Travels into politically falsifying amendments of true knowledge and question what kind of political atmosphere these falsifications create. This paper also interprets these elements in contemporary political terms within Foucauldian concepts of power and Bakhtinian concepts of laughter through a cross cultural reading of Swift in comparison to the texts of the Czech writers Milan Kundera and Franz Kafka, and the Turkish writers Oya Baydar and Aziz Nesin.
\end{abstract}

Keywords: Cultural Solipsism, Identity, Ethnicity, Nationality

Öz: Kamusal bir karakter olarak entelektüel kendi toplumunun siyasetinde önemli bir rol oynayan ve düşünce dünyasına katkıda bulunan bir bireydir. Entelektüel kimliği üretken ve topluma faydalı bir kimlik olarak tanımlamak her zaman zor olmuştur. Güliver'in Gezileri romanında Jonathan Swift zamanının siyasetini ve entelektüelin yerini, kime entelektüel dendiğini, niçin entelektüel olarak adlandırılmayı hak ettiğini sorgulamıştır. Güliver'in Gezileri romanı akademisyenlerin bilim dünyasının "sahtekâr” sözcüleri olarak tanımlandığı alternatif bir dünya kurgulamıştır. Lemuel Gulliver seyahat ettiği fantastik ülkelerdeki siyasi atmosferi analiz eden ve yorumlayan siyasi bir karakter olarak karşımıza çıkmaktadır. Bu çalışma; Güliver'in Gezileri romanında entelektüellerin gerçek bilimsel bilgiyi siyasi olarak değiştiren kişiliklere nasıl dönüştüklerini ve bu değişimlerin nasıl bir siyasi ortam yarattığını sorgulamayı amaçlamaktadır. Bu çalışmada bu öğeler çağdaş siyasi terimler çerçevesinde yorumlanacak ve Foucault'nun güç kavramı ile Bakhtin'in kahkaha kuramı kapsamında çözümlenecektir. Aynı zamanda romanın Çek yazarlar Milan Kundera ve Franz Kafka ile Türk yazarlar Oya Baydar ve Aziz Nesin ile karşılaştırmalı bir okuması da sunulacaktır.

Anahtar sözcükler: Kültürel Bencillik, Kimlik, Etnik Köken, Milliyet

As one of the pioneer examples of political fiction, Jonathan Swift's Gulliver's Travels traces the story of Captain Lemuel Gulliver into several fantastic lands/worlds where he satirically compares the cultural and political conditions of these lands to his homeland. In doing so, he

\footnotetext{
* Doç. Dr. Pamukkale Üniversitesi, Fen-Edebiyat Fakültesi, İngiliz Dili ve Edebiyatı Bölümü, Denizli. macelikel@pau.edu.tr
} 
employes grotesque images and laughter in order to satirise the concepts of power, identity and nationality by depicting these imaginary nations and kingdoms in a fantastic ontology. Captain Gulliver takes over the role of an intellectual who, voluntarily, attempts to understand the legal and social regulations of his country and the countries he travels to, where he questions his observations and, as an intellectual, investigates with in-depth analysis the way governmental systems work. This paper aims to study the novel from the perspectives of laughter and power to define the function of the intellectual as a public figure. This paper also analyses how the elements that may create difficulties for intellectuals are translated in Gulliver's Travels into political manipulations of true knowledge and questions what kind of political atmosphere these manipulations create, presenting a cross cultural reading of Swift in comparison to the contemporary texts of the Czech writers Milan Kundera and Franz Kafka, and the Turkish writers Oya Baydar and Aziz Nesin.

Edward Said argued that intellectual is someone "who ought to be listened to as a guide to the confusing present, and also as a leader of a faction, tendency, or group vying for more power and influence" (20). The intellectual as a public figure exists to contribute to the world of ideas and plays a key role in the politics of his or her own society. The term intellectual has been defined according to the changing conditions and needs of the various periods of history. Almost exactly three centuries ago, Jonathan Swift in a humorous way questioned the politics of his time and the place of the intellectual in Gulliver's Travels, leaving aside the question as to who was an intellectual and why he or she deserved to be called one.

For the purposes of political relativity, laughter in Gulliver's Travels is presented through the grotesque and hyperbolic images in the beginning of the novel. When Captain Gulliver arrives on Lilliput, he wakes up to find himself tied to the ground by tiny strings and sees dozens of Lilliputians walking over his body. His captivity is followed by his meeting with the Lilliputian king who orders his servants to provide Gulliver with as much food as he wants. Upon this, Gulliver begins to consume food and drink "sufficient for the support of 1728 Lilliputians" (GT 39). The greedy image portrayed by his eating excessive amount of food leads him to entertain even more grotesque images:

I had been for some hours extremely pressed by the necessities of nature; which was no wonder, it being almost two days since I had last disburdened myself. I was under great difficulties between urgency and shame. The best expedient I could think on, was to creep into my house, which I accordingly did; shutting the gate after me, I went as far as the length of my chain would suffer, and discharged my body of that uneasy load. (GT 21)

"Exaggeration becomes a caricature" states Mikhail Bakhtin (62). The abstract ideas that distort the "nature of grotesque image" transform the "centre of gravity to a 'moral' meaning" and submits "the substratum of the image to the negative element" (Bakhtin 62). Swift's depiction of the grotesque in Gulliver's fantastic adventure in fully exaggerated images caricaturises Gulliver's exploration. As a semi-intellectual white European, Gulliver witnesses the change in the concepts of power and realises the fact that his gigantic size may bring him weakness depending upon the circumstances. In Bakhtinian terms, the grotesque images "selected to serve an abstract idea are still too powerful; they preserve their nature and pursue their own logic, independently from the author's intentions, and sometimes contrary to them" (Bakhtin 63). The grotesque laughter in the novel powerfully politicises Gulliver's situation. The concept of power becomes a relative concept and, by changing perspectives, he realises that being big does not necessarily mean being powerful, as the his most intimate moments such as "discharging [his] body of [an] uneasy load" could be seen by everybody. 
The hyperbolism of "material bodily images", as pointed out by Bakhtin, reveals "the devouring and generating lower stratum" (64). Gulliver is reduced to the Bakhtinian "lower stratum" which is also considered to be the "peculiar festive character of the material bodily principle" (Bakhtin 64). However, neither this abstract idea penetrates "the depths of the image and does not become its organizing principle", nor "is laughter fully transformed as yet into mockery" (Bakhtin 64). Thus, Gulliver's body becomes a political medium of the representation of power. Gulliver, then, contemplates becoming a public figure and learns the local language to understand the truth not only about the host culture, but about his own.

Swift's satirical depiction of intellectuals as isolated researchers begging for money on their useless projects indicates that Gulliver's Travels suggests an alternative world in which academics are depicted as spoofs, the profane spokespersons of scientific knowledge. His satire discards the concept of the intelligentsia from what it actually denotes in practice and places the intellectuals in a dysfunctional state of being. Said considers Swift as "the most devastating pamphleteer of his time" (27) in his criticisms and campaigns against the political authorities of his time. In a sense, Swift's degrading portrayals of intellectuals may be interpreted as the satirical reversals of his own attitude in practice. Said points out that Swift has in mind "the running quarrel between ancients and moderns in which venerable writers like Homer and Horace had the advantage of great longevity, even permanence" (27). Thus, Gulliver's Travels contains sections in which even the historical figures and records are questioned.

In Glubbdubdrib, the Island of Sorcerers, the Governor orders Gulliver to call up any historical figure to their presence and ask whatever questions he might want to ask. Thus, Lemuel desires to see Alexander the Great first:

Alexander was called up into the room: it was with great difficulty that I understood his Greek, and had but little of my own. He assured me upon his honour that he was not poisoned, but died of a fever by excessive drinking (GT 214).

Angus Ross asserts that "Jonathan Swift's life, character, and writing are distinguished not merely by the normal tensions and contrasts of human experience, but by the powerful clash of violently opposed forces" (xi). According to Ross, "Swift was a political animal", and his political texts "form a very substantial part of his achievement, and his preoccupation with politics and politicians ran" through his texts (xxiii). In Glubbdubdrib again, Gulliver learns about the modern history and is disgusted by it. He listens to three kings who confess that "in their whole reigns they never did once prefer any person of merit" and they show him with "great strength of reason that the royal throne could not be supported without corruption" (GT 219). Gulliver, then, discovers the role of corruption and takes over the role of a public intellectual who feels the responsibility to, in Edward Said's words, guide the society:

I was surprised to find corruption so high and so quick in that empire, by the force of luxury so lately introduced, which made me less wonder at many parallel cases in other countries, where vices of all kinds have reigned so much longer, and where the whole praise as well as pillage hath been engrossed by the chief commander ... (GT 221).

As well as intellectuals, those who hold the power are also depicted as the proprietors of public space that they forcibly dominate the cultural atmosphere, which turns the novel into a political satire. Lemuel Gulliver, then, stands out as a public intellectual who has to analyse and interpret the political atmosphere of the fantastic lands he travels to. Jonathan Swift's criticism of governmental systems increases in the land of Houyhnhnms where they have no terms for "power, government, war, law, punishment, and a thousand other things" (GT 269). In such a 
place, Gulliver tells the Houyhnhnm master about the function of a Chief Minister of State and how he runs a country:

I told him that a First or Chief Minister of State, who was the person I intended to describe, was a creature wholly exempt from joy and grief, love and hatred, pity and anger; at least made use of no other passions but a violent desire of wealth, power, and titles ... he never tells a truth but with an intend that you should take it for a lie; nor a lie but with a design that you should take it for a truth (GT 281-2).

Michel Foucault firmly suggests that "[p]olitical power was the essential personage", because "[p]ower was exercised first of all by posing questions, by interrogating; it did not know the truth and sought to discover it", therefore, in order to determine the truth, "power appealed to the notables, to the persons fit to know, given their position, their age, their wealth, their notability, etc." (Foucault 45). Swift's assertion from this perspective is essentially important:

"The palace of a chief minister, is a seminary to breed up others in his own trade: the pages, lackeys, and porter, by imitating their master, become ministers of state in their several districts, and learn to excel in the three principal ingredients, of insolence, lying, and bribery" (GT 282).

As opposed to the power used by the rulers of the state, Achille Mbembe argues that the "practices of ordinary citizens cannot always be read in terms of 'opposition to the state,' 'deconstructing power' and 'disengagement”, because "an intimate tyranny links the rulers with the ruled - just as obscenity is only another aspect of munificence, and vulgarity a normal condition of state power" (Mbembe 66). When the tyrant portrays himself as an intimate figure, the ruled masses feel attached to the tyrant and put no effort to free themselves from this tyranny. This attachment can be achieved by the Chief Minister through the creation of a suitable epistemology that consolidates this power. As Mbembe asserts:

[T] he subjects of the commandement have internalised authoritarian epistemology to the point where they reproduce it themselves in all the major circumstances of daily life - social networks, cults and secret societies, culinary practices, leisure activities, modes of consumption, styles of dress, rhetorical devices, and the whole political economy of the body (66).

With the power of this 'authoritarian epistemology' created by the commandment, namely presidency, the perception of individuals about their own existence and their body is shaped by the authority. When Gulliver is outside this authority and has a chance to view himself and his species as represented in the form of the filthy Yahoos, he becomes politically conscious of his identity. After observing the Yahoos as the representatives of humanity, he realises that he has a false pretention of his own cultural identity as a civilised entity. This leads him to self-criticism. In Mbembe's assumption, this results in "pretense (le smilacre)" that becomes "the dominant modality of transactions between the state and society, or between rulers and those who are supposed to obey" (67). Taking over the role of an intellectual, Swift, through the consciousness of Gulliver, shares this knowledge with us, making his readers conscious of the corruption that surrounds the society. So, "instead of keeping silent in the face of obvious official lies and the effrontery of elites, [Gulliver's] body breaks into laughter" and by laughing, "it drains the officialdom of meaning and sometimes obliges it to function while empty and powerless" 
(Mbembe 66).

Ashcroft et al., for that matter, draw an important link between "power and knowledge" in the Foucauldian premise (10). Now, says Foucault:

[W]e need to explain the establishment of the judgement [sentence], to explain how one reached the end of a process in which one of the principal figures was the prosecutor. If the main victim of an infraction was the king, if the prosecutor was the primary plaintiff, it is understandable that judicial settlement could no longer be obtained through the mechanisms of the test. The king or his representative, the prosecutor, could not risk their own lives or their own possessions every time a crime was committed (43-44).

Therefore, the ruling power is always manipulative for the good of its welfare. For the protection of the powerful position, a 'king' needs a representative, or in Swift's terms, ' $a$ favourite':

... there was a sort of ruling Yahoo ... who was always more deformed in body and mischievous in disposition than any of the rest. That this leader had usually a favourite as like himself he could get, whose employment was lick his master's feet and posteriors ... This favourite is hated by the whole herd, and therefore to protect himself, keeps always near the person of his leader (GT 290).

This kind of manipulative and deformed leader creates false pretentions to justify his misdeeds and generates new forms of crime particularly attributed to the intellectuals or academics. In a similar way, in Franz Kafka's The Trial, when K. is arrested, he is faced with the fact that the reason of his arrest is a falsified and an imagined form of offense unknown and undefined by any written law:

“...There can be no mistake about that. Our officials, so far as I know them, and I know only the lowest grades among them, never go hunting for crime in the populace, but, as the Law decrees, are drawn towards the guilty and must then send out us warders. That is the Law. How could there be a mistake in that?" "I don't know this Law," said K. "All the worse for youwa" replied the warder (T 12-13).

Intellectuals, to quote Said once again, should be listened to "as a guide to the confusing present" (20) in order for the public to have an awareness of what the circumstances are. In Milan Kundera's The Book of Laughter and Forgetting, in the aftermath of the Russian invasion of Czechoslovakia, the position of the intellectual is that of an insensitive and indifferent individual similar to those intellectuals depicted in Gulliver's Travels as those isolated from the outside world:

In the political jargon of the day "intellectual" was an expletive. It designated a person who failed to understand life and was cut off from the people.... Unlike people with their feet planted firmly on the ground, they supposedly floated in the air. In a sense, then, it was only fair they have the ground pulled out from under them once and for all and be left there hanging slightly above it (BLF 5). 
Kundera describes the intellectuals as people who "have calluses on their backsides and hold hands, they go to meetings, denounce their fellow [citizens], lie, and make love" (BLF 21). He considers them insensitive to the blows on their backs which are protected by their "calluses".

The manipulation of history is one of the most influential ways of hiding the truth from the people. A similar theme may also be seen in Oya Baydar's The General of the Garbage Dump [Çöplüğün Generali] in which the country's history is rewritten after a breaking point referred to as the "big bang" in its history. In Foucauldian terms, "there is continually produced within [history] a separation of true and false" (Foucault 233). The General of the Garbage Dump, recounting the history of a new city/state after a "big bang", centres on characters who find themselves at the critical breaking point of coming to terms with the historical truth concealed with falsified knowledge (See Çelikel 2014). In the opening passage of the novel, the narrator plunges into a research of a mysterious past with questions:

O gün orada ne oldu? Kimse bilmiyor, hatırlamiyor. Olanı olmayanı, gerçeği yalanı yaymakta birbirleriyle yarışan gazetelerin, televizyonların arşivlerinde büyük depremle ilgili - çoğu birbirini yalanlayan haberler, hepsi aynı bilgilendirme merkezinden çıkmış fotoğraflar, video-filmler, bir de resmi açılamalar var (7).= What happened there, that day? No one knows, no one remembers. There are only pictures, videos and official statements, all from the same information centre, in addition to the news - most of which refute each other - about the big earthquake in the archives of television companies and newspapers that compete with one another in spreading the truth and lies about what happened and what did not happen (7).

The relation between power and history is portrayed in the form of official state control over science and historical data in dystopian novels about catastrophic future societies. The hegemonic state control is maintained via the reconstruction of history and the reshaping of individual memory through the deletion of records, the manipulation of resources and moreover the induction of scientific studies to strengthen the power of hegemony (See Çelikel 2014).

The manipulation of truth by a hegemonic power holder could only be overcome by intellectuals who fulfil their public role. However, if, as in Kundera's The Book of Laughter and Forgetting or as the isolated scientists in Swift's Gulliver's Travels, they are unaware and uninformed to guide the society, the manipulated truth will be utilised to confine that society. A similar example is found in Aziz Nesin's Ah Biz Eşekler [Us Donkeys], which is an allegoric story that illustrates donkeys as animals who could once speak like humans. While the narrator/donkey grazes on the meadows one day, he hears the voice of a wolf in the distance. He raises his ears but decides that it cannot be a wolf. Seconds later, the wolf's voice comes closer, and he does not care. When the wolf's voice is recognisably closer, he turns his head to see the wolf running after him. While he escapes, he is still doubtful whether this is a wolf or not. Only when the wolf bites his hind legs, does he realise for sure that this is a wolf. That is the moment when donkeys lost their ability to speak like humans and began to bray. He becomes breathless and says, stammering, "Ah, that's really a wolf, hee, ah, he is a wolf, ah, now I know, hee, heehaw, hee-haw...”. This stammering leads them to a lifetime of braying.

To conclude, humour functions to suggest the ideological standpoint of the authors. The author as the intellectual uses political metaphors through humorous depictions of characters and settings. The truth, even when it is concealed by authority, is revealed through humour. The 
intellectual writer as a public figure, then, has the responsibility to talk about the manipulated truth and reveal the hidden reality. Throughout the centuries, from Swift to Kafka, Kundera, Baydar and Nesin, a cross cultural and trans-historical reading indicates that political powers have always had a tendency to create false pretentions and manipulate the truth and formed their own system of justice to maintain their hold on power. In order to maintain public welfare and keep the society informed, as the intellectual writers in this paper suggest, the society, regardless of geographical and historical differences, should always be informed about the tyranny that manipulates the truth, in the time left before the wolves render us speechless as in Aziz Nesin’s allegory.

\section{KAYNAKÇA}

Ashcroft B., Griffiths G. \& Tiffin H. (2006). “General Introduction”. Eds. B. Ashcroft, G. Griffiths \& H. Tiffin, The Post-Colonial Studies Reader $\left(2006^{2}\right) 1$ 1-13. London \& New York.

Bakhtin M. Rabelais and His World. (1984). Trans. H. Islowsky. Bloomington 1984.

Çelikel M. A. (2014). "Annihilation of History and Fear of the Past in Oya Baydar's The General of the Garbage Dump”. Edebiyat Fakültesi Dergisi 31/1 (Haziran 2014) 125-36.

Foucault M. (2000). Power. Ed. J. D. Faubion. New York 2000.

Kafka F. (1987). The Trial. Trans. W. Muir \& E. Muir. London 1987.

Kundera M. (1983). The Book of Laughter and Forgetting. Trans. M. H. Heim. London1983.

Mbembe A. (2006). "The Intimacy of Tyranny”. Eds. B. Ashcroft, G. Griffiths \& H. Tiffin, The PostColonial Studies Reader $\left(2006^{2}\right)$ 66-69. London \& New York.

Ross A. (2008). "Introduction”. Major Works (2008) xi-xxviii. Oxford.

Said E. (2002) "The Public Role of Writers and Intellectuals". Ed. H. Small, The Public Intellectual (2002) 19-39. Oxford.

Swift J. (1994). Gulliver’s Travels. London 1994. 